\title{
Pharmacological and Non-Pharmacological Treatment of Headaches in Early Modern Cretan Healing Manuals
}

\author{
By Steven M. Oberhelman *
}

\begin{abstract}
The treatment of headaches and migraines have been a major concern in Greece since Hippocrates. Ancient and Hellenistic Greek physicians gave many discussions of the symptoms of cephalalgia and their treatment, while Byzantine medical writers added to those descriptions and offered new therapeutic methods. On the island of Crete, during the Venetian occupation (1205-1669), medical students, after their studies at the great European universities, brought back classical and Byzantine knowledge of healing diseases, including headaches. But after the Ottoman Turks seized the island, practical doctors handled medical prophylaxis. These folk healers preserved their knowledge in treatises called iatrosophia for use by their neighbors and friends. In this paper, I analyze passages from two Cretan iatrosophia for their description and treatment of headaches and migraines. Some recipes are drawn from classical and Byzantine formal medical texts, but others are traditional medical cures preserved over the centuries by villagers and practical doctors and consist of natural pharmacological ingredients (plants, herbs, animal substances, minerals). But because these treatments were sometimes ineffective, the iatrosophia also offer headache remedies containing magical spells, phylacteries, exorcisms, and prayers. Such multiple approaches to healing (natural, supernatural, supranatural) reflected a cultural mindset that welcomed any and all forms of healing.
\end{abstract}

Keywords: History of medicine, Magic, Pharmacology, Traditional medicine

The ancient Greeks approached the treatment of headaches from three main methods: medico-pharmacological (cures offered by physicians, rootcutters, and druggists), religious (for example, the healing cult of the god Asclepius), and magical (for example, the incantations and exorcisms in the Greek Magical Papyri). People did not hiercharize such treatments but freely used one or the other; any method that could bring relief from the pain or result in a cure was viable. ${ }^{1}$

The medical writings ascribed to Hippocrates refer to both headaches and migraines (Rose 1995: 1, Rapaport and Edmeads 2000: 1222, Magiorkinis et al. 2009, Koehler and Boes 2010: 2491-2492, Eadie 2012: 39-50). Hippocrates was the first person to recognize and describe aura that migraine sufferers experience. He wrote that patients see a bright light, usually in the right eye, followed by extreme pain in the temples and eventually the entire head; vomiting often helps. ${ }^{2}$ Hippocrates observed that headaches may have many causes. Some headaches are symptomatic of the onset and course of a disease. Others come from imbalances of

* Professor of Classics, Holder of the George Sumey Jr Endowed Professorship of Liberal Arts, and Associate Dean, Texas A\&M University.

${ }^{1}$ This multiple approach to the healing of headaches may be seen in Assyrian and Babylonian tablets and in Egyptian medical papyri from the second and first millennia BCE; see, e.g., Dijk and Geller (2003), Eadie (2012: 35-39), Karenberg and Leitz (2001), and Zayas (2007).

${ }^{2}$ Monette (2012) points out that emetics are used for headaches in Islamic medicine. 
humors that circulate in the body from the liver to the head. Still others are caused by exercise and sexual relations or even by stress. External factors like climate and weather or food and drinks can also result in a headache. In the Hippocratic corpus, bleeding a patient was recommended so as to drain the excess humors. Humors could be drawn out also by applying to the head plant like hellebore or poultices made of iris mixed with vinegar and rose perfume. For chronic headaches, the juice of a squirting cucumber was used. Interestingly, Hippocrates recommended the powder made from the willow tree's bark and leaves to treat headaches. The substance in willow plants, called salicin, gives us modern aspirin (Norn et al. 2009).

Subsequent Greek physicians refined Hippocratic ideas about headache. The first-century CE physician Aretaeus of Cappadocia described three types of headache: (1) cephalalgia, which is sporadic, mild, and lasted for one or two days; (2) cephalaia, which is a severe form of head pain and often hard to be treated; and (3) heterocrania, which occurs on one side of the head and is equivalent to our modern migraine (Rose 1995: 1-2, Rapaport and Edmeads 2000: 1222, Koehler and Boes 2010: 2490-2492). Galen, a doctor of the second century CE, distinguished between the chronic headache and the hemicrania (Rose 1995: 2, Trompoukis and Vadikolias 2007: 1063-1064). Galen attributed both the migraine and the headache to harmful humors, especially yellow bile, which reach the brain from the other parts of the body. Other causes include drinking wine, stomach ills brought on by food, wounds, and cold. Galen used many substances, such as opium, and even electricity by applying electric sea rays to the patient's cranium and allowing the electricity to pass until the patient was healed.

Some patients went to the sanctuaries of healing gods, in particular Asclepius. ${ }^{3}$ In this cult's ritual, one slept at night in the sacred precincts of the temple or in the sleeping-chamber and received healing directly at the hand of the god, or indirectly through a dream that the god sent him. On awakening, the patient was cured, or he followed the instructions in the dream to achieve a cure. Five votive tablets, which survive from the Asclepian healing sanctuary at Epidauros, tell of the miraculous healings that took place there. ${ }^{4}$ For example, in stele B cure number 9, we read:

Agestratos suffered from insomnia on account of headaches. As soon as he came to the abaton, ${ }^{5}$ he fell asleep and had a dream. He thought that the god cured him of his headaches and, making him stand up, taught him wrestling. When day came, he departed cured, and after a short time, he competed at the Nemean games, and was victor in wrestling.

\footnotetext{
${ }^{3}$ Good starting points on this cult is Edelstein and Edelstein (1945), Roebuck 1951 (headaches at Corinth sanctuary), Pfohl (1977), LiDonnici (1995), Wickkiser (2009), and Steger (2017).

${ }^{4}$ The texts may be found in Herzog (1931), LiDonnici $(1992,1995)$ for analyses of the texts; Renberg (2017: vol. I: 171-178). Ploeg (2018) divides the stories on the stelai into medical and divinatory (see the discussion in her chapter 2).

${ }^{5}$ The abaton was the building structure at an Asclepian sanctuary where a suppliant slept at night; the god would then heal him of his ailment or would communicate a cure through a dream.
} 
Suppliants, after they were healed, dedicated replicas, usually in terracotta, of the body parts that were healed. At Corinth and Athens we have remains of heads that symbolize the curing of headaches (Oberhelman 2014, also LiDonnici 1992: 137-140, and 1995: 41-43).

Plants and herbs were recommended by ancient druggists and root-cutters. The first-century CE pharmacologist and botanist Dioscorides wrote a lengthy work (in five books) on the properties and uses of plants in medical treatments. ${ }^{6}$ I offer below just a few of the many treatments for headaches that Dioscorides offers:

Dried roses boiled in oil and drunk

Seed of the vitex agnus-castus applied as a poultice

Root of bitter almond tree bruised and boiled and then applied with vinegar and rose oil to temples and forehead

Wool with vinegar and rose oil applied to head

Sesame with rose oil for heat-induced headache

Leaves of mint laid on temples and forehead

Thyme with vinegar and rose oil dripped onto head

Aloe with vinegar and rose oil applied to forehead

Peppermint applied to forehead

Rue pounded fine and applied with rose oil and vinegar

Anise inhaled through the nostrils

Common hogweed with oil dripped onto head

Squirting cucumber with milk poured into the nostrils

Leaves and tendrils of the grape vine

Leaves and berries of the myrtle tree

Butcher's broom

Rush plant

Roseroot

Betony

Fleabane

Melanthion

Seawater inhaled as steam

Fruit of the wild vine mixed with vinegar and rose oil and inhaled

Many of these are proven herbal remedies as modern folk pharmacological encyclopedias and ethnopharmacology tell us. For example, rose vinegar is commonly used for headaches, and the leaves of peppermint and of rue are often placed on the aching area of the head. ${ }^{7}$

\footnotetext{
${ }^{6}$ Of all the many studies of Dioscorides, I mention here only Riddle (1985), since Riddle analyzes the pharmacological properties of Dioscorides' materia medica and in modern medical research. The best text for Dioscorides remains the three-volume text by Wellmann (1906-1914).

${ }^{7}$ For a parallel, Zarshenas et al. (2013) review the headache as it appears in pharmacopeias and other medical manuscripts of traditional Persian medicine. These texts deal with over 20 various types of headache and more than 160 different medicinal plants administered for oral, topical, and nasal application. Nearly $60 \%$ of the medicinal herbs referenced have related antiinflammatory or analgesic effects as determined by science.
} 
If religion, Hippocratic medicine, and folk remedies were not effective, magical methods like amulets and phylacteries were used. Many of the Greek magical papyri contain incantations and spells for the relief of headache pain. ${ }^{8}$ One amulet, dated to the early second century CE and meant to relieve a migraine or cluster headaches, reads:

Turn away, O Jesus, the Grim-Faced One, and on behalf of your maidservant, her headache, to (the) glory of your name, Iaô Adônai Sabaôth...Ouriēl... Ouriēl...Gabriēl. ${ }^{9}$

Another reads: "Lord Sabaôth, repel the pain from me, the headache, I pray, take [from me]," while another spell for migraine headache goes: "Take oil in your hands and utter the spell: 'Zeus sowed a grape seed: it parts the soil; he does not sow it; it does not sprout'." ${ }^{10}$ The latter spell is similia similibus: just as the seed does not sprout, so the headache will not grow.

This same pattern of a multiple approach to curing headaches or removing their pain - formal and informal medicine and pharmacology, religion, and magic - occurs in the Byzantine period of Greece. Byzantine physicians continued ancient Greek medical discussions of the headache (Rose 1995: 2-3, Trompoukis and Vadikolias 2007). Oribasius (fourth century) distinguished between acute and chronic headaches, and described the effects of migraine. He recommended the importance of good diet, lots of liquids, and sleep as a way to prevent headaches. Herbal ointments and poultices, especially with rose oil, eliminate pain. Alexander of Tralles (sixth century) offered a whole typology of headaches based on causation, such as heat, cold, fever, wine drinking, and wounds. He also gave for each type of headache various herbal and vegetable compounds for dressing the forehead. Paul of Aegina (seventh century) built upon the theories of Alexander and described the migraine in greater detail. He warned that severe headaches can come from undue stress levels in one's life or from excess humors; if humors are responsible, then the physician should bleed the patient by opening the veins in the nose.

Religious texts of the Byzantine era show that saints healed headache through incubation methods or through invocation in prayer. ${ }^{11}$ Saint John the Baptist, in Greek Orthodox theology, was given the grace of healing headaches (in the western Catholic Church, Saint Teresa of Avila has this grace). Biographers of saints' lives record dreams sent by the saints to sufferers. In the Miracles of Saint Cyrus and Saint John (cap. 18), for example, we read that a

\footnotetext{
${ }^{8}$ I refer the reader to only a few discussions, as the bibliography on magic and medicine is immense. In the context of ancient and Hellenistic magic and medicine see Kotansky (1991) (an excellent introduction to the subject with extensive bibliography); for headaches specifically, see Barb (1966), Bradshear (1979), Kotansky (1980).

${ }^{9}$ Taken from Kotansky (2002), who offers a full discussion and commentary.

${ }^{10}$ Papyri Magicae Graecae XVIIIa.1-4 and VI.199-201; taken from Betz (1992: 255 and 121, respectively); see also the spell with commentary and bibliography in Betz (1992: 317).

${ }^{11}$ Again, the bibliography is immense; see, for an introduction and survey, Talbot (2002); also the articles in Oberhelman (2013), Csepregi (2007), Csepregi and Burnett (2012), Graf (2014), Renberg (2017: vol. II: 743-807), for a comprehensive bibliographical survey.
} 
man suffering from headaches was told to go to a certain door of the church and strike the first person whom he met. The order was given three times before he obeyed. A soldier met him and returned the blow with a heavy stroke of his stick on the man's head, thus curing him. ${ }^{12}$ Another biographer records how Saint Gregory Palamas cured a priest-monk who had suffered from migraines for seven years (Talbot 2010). Religious materials also can cure. People afflicted with severe headaches, it is recorded, could relieve their pain by taking the hemp of the cord holding the lamp before the icon of Saint Stephen in Hagia Sophia, and then wrapping it around their heads (Carr 2003: 84 note 58$)$.

Just as in antiquity, Byzantine people resorted to magical incantations and amulets to ward off or cure headaches. Two charms, which are to be written down, placed into foil or an amulet, and then worn on the head or around the neck, call upon divine help or contain exorcism prayers:

Holy John, prophet and baptizer of our Lord Jesus Christ, you who have as your father the holy Zacharias and as your mother the holy Elizabeth, you baptized our Lord Jesus Christ in the Jordan River [fol. 74r], which you traversed, you who took into your hand the holy head and lived in the desert: heal the pain of the migraine of the slave of God, and [if so,] he will sing your praises for the days of his life and will glorify your holy memory, just as we sign the praises and glorify the all-honorable and magnificent name of you, the Father and Son and Holy Spirit. $\sigma . \mu . \kappa . \quad \lambda . \sigma . \mu . \mu . \tau . \varphi . \beta . \theta \varepsilon o v .{ }^{13}$ Amen. Erothonios, Ablatha, Nathanaēl, Onios, Thathaēl, Ieliô, Athenaphron, Iathenophronēs, Ôrē,

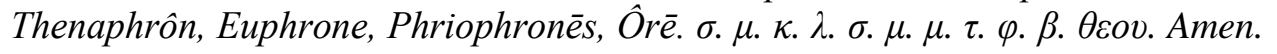
In the name of the Father and son and Holy Spirit. Liakops Lilaps, cure the pain of this migraine and the whole head [fol. 74v] for the slave of God. $\sigma . \mu . \kappa . \lambda . \sigma . \mu$. $\mu$. $. \varphi . \beta . \theta \varepsilon o v$. Amen.

[fol. 74v] A phylactery for the head: O Lord God of our fathers Abraham, Isaac, and Jacob, set free the pain in the head of NN, the slave of God, [set free] the migraine. I adjure you, every unclean thing always sitting on the head of the slave of God: withdraw from the one who has the pain in his head and keep closely [to yourself] the migraine. Trophon Skoudaos, come out of $\mathrm{NN}$, the slave of God. Mikhaèl, Gabriēl, Ourouèl, and Raphaèl. In the name of the Father and the Son and the Holy Spirit, now and always and for ever and ever. Amen. ${ }^{14}$

After the collapse of the Byzantine Empire, scholars fled Greece for the West. On Crete and the mainland, the practice of medicine was mostly relegated to monasteries where there were collectives of healing practitioners. ${ }^{15}$ Most cures, though, were carried out by local practical doctors (praktikoi iatroi), priests and monks, and village old women who knew the properties of local herbs and

\footnotetext{
${ }^{12}$ Story described in Hamilton (1906: 155).

${ }^{13}$ The Greek letters are abbreviations for the prayer spoken by the Eastern Orthodox priest in the Divine Liturgy: "Let us stand well, let us stand with the fear of God."

${ }^{14}$ Both texts are in Bibliothèque de la Société Historique Codex 210. All translations in this article are mine unless otherwise noted.

${ }^{15}$ See the discussion in Clark (2011: chapters $\left.1-2\right)$, with recent bibliography.
} 
plants and who were acquainted with centuries-old folk remedies (Hionidou 2016). Proprietors of pharmacy shops and marketplace booths could, as they even do today, also recommend a treatment of aromatics, plants, and vegetables when consulted by a sufferer (Hanlidou et al. 2004).

Priests, practical doctors, and other medical healers were assisted in their cures by relying on manuscripts called iatrosophia. ${ }^{16}$ An iatrosophion is a collection of medical recipes taken from classical and Byzantine medical treatises (for example, the writings of Hippocrates and Galen, or the writings of Paul of Aegina and Alexander of Tralles) and from pharmacological works like Dioscorides' massive work on plants, and supplemented by new medical knowledge and new medical substances from the New World, the Middle East, and the Far East. Thus, iatrosophia gradually incorporated discussions of the "French disease" (that is, syphilis) and new substances like coffee, quinine, and tobacco alongside ancient home garden herbs like rosemary and oregano.

There were two basic types of iatrosophia. One type, which was linked either to monasteries and was penned by monks or to hospitals and was written by doctors, contains only medical recipes and therapeutics (Lardos 2006, 2012, Lardos and Heinrich 2013). Most recipes in the texts consist of herbal concoctions, with others containing minerals or animal substances. The majority of recipes derive from ancient and Byzantine formal medicine, but we have as well the pharmacopoeia of folk healing.

An example is the iatrosophion ascribed to the monk-physician named Meletios and dated to the late twelfth or early thirteenth century. The book is typical of the text that physicians working at hospitals of the middle Byzantine period used. Entries are brief: a header that describes the ailment and then one to four or five therapeutic recipes, mostly drawn from classical and early Byzantine sources. Most commonly used are Dioscorides' On Medical Substances and Galen's treatises On Readily Available Medicines and the Mixtures and Properties of Simple Drugs. A number of early to middle Byzantine physicians, who wrote recipe books themselves, are quoted: the fourth-century author Oribasius (Collections and Synopsis for Eustathius), the sixth-century Aëtius of Amida and Alexander of Tralles, and Paul of Aegina (seventh century). For example, for curing a headache, Meletios writes:

For headache. Take cress, vinegar, and rose oil. Parch the cress and make it like flour. Mix everything together. Rub onto the patient's head.

This recipe is very similar to what we read in three famous texts and shows how the iatrosophist gleans classical and Byzantine texts for his recipe book:

Galen, De remediis, II (Kühn 14.400.9-12): Roast cress in vinegar and rose oil and make a thick salve. Put this on from one temple to the next. This instantly stops the pain.

\footnotetext{
${ }^{16}$ Basic studies on the iatrosophion are Tselikas (1995), Alexopoulou (1998), Bennett (2000), Papadogiannakēs (2001), Touwaide (2007), Papadopoulos (2009), Clark (2011), DemetriadesHadj (2015), Valentino (2017).
} 
Aëtius of Amida, 6.50 (Oliveri 2.193.2-3): Roast cress with vinegar and rose oil and make a thick salve. Place it on and he will be healed immediately.

Paul of Aegina, Epitome medica 3.4 (Heiberg 1.138.10-11): A patient benefits from cress roasted and triturated in vinegar and rose oil.

The second type of iatrosophia also contains remedies drawn from folk medicine and classical Greek medicine; but besides the medical recipes and treatments, there are sections on a variety of topics like agricultural and veterinarian matters, astrology, exorcisms and spells, magic, and religion.

The remainder of this paper concerns two iatrosophia that belong to this second category and that come from the island of Crete. My purpose here is to discuss the many different treatments for headache which appear in the iatrosophia. One text dates to around 1800. The author is called Anagnōstēs, that is, "The Reader," according to a note dated 23 February 1978. The text was passed down in his family, the Kharalampos family from the village of Nippos outside of Khania. ${ }^{17}$ The other iatrosophion was the personal notebook of Nikolaos Konstantinos Theodorakis (1891-1979). The notebook was autographed on 10 August 1930. Theodorakis, an herbalist and expert in local flora, dispensed remedies in his home and at his tobacconist shop to patients. Some recipes came from his own experimentation on local flora, while others were based on folk and medical traditions that reached back centuries, even millennia, earlier. ${ }^{18}$

Anagnōstès followed Hippocratic theory on the causation of headaches. Humors come from the body and settle in the head; these must be purged to restore proper humoral balance. Methods are as follows:

Crush leaves of the pine tree and place the juice in the person's nose. Grind black cumin finely; stir in woman's breast milk and place this [mixture] in the patient's nose. Pestle cyclamen and place the juice in the nostrils. Crush black cumin finely and then mix it with anointing oil; let it sit and then smear it in your nose. (Papadogiannakēs 2001: 61-62) ${ }^{19}$

An accumulation of phlegm can also cause headaches and must be purged too:

Take a jar of vinegar and boil it along with hyssop, pennyroyal, oregano, and marjoram. Let these juices ferment. [Place and] keep in the mouth to draw out many fluids. Mix crushed ginger and stavesacre; one should then chew this. Crush very finely stavesacre and pepper and then add mastic gum. Chew this in order to expel many fluids. Take stavesacre, vinegar, pennyroyal, thyme, and oregano. Seethe these and then keep in the mouth so as to produce much sputum and spittle. (Papadogiannakēs 2001: 60-61)

\footnotetext{
${ }^{17}$ There is a long passage on this in the iatrosophion; see Papadogiannakēs (2001: 132-133); for an excellent introduction to the work see Papadogiannakēs (1990).

${ }^{18}$ Clark (2011: 31-45); in greater detail, Clark (2002).

${ }^{19}$ All translations from Papadogiannakēs' (2001) text are my own; I quote from the page of this edition. For Theodorakis' iatrosophion I have used the translation in Clark (2011).
} 
Many of these ingredients not only go back to classical and Byzantine pharmacological works but are still used in folk herbal remedies. For example, in pharmacopoeias hyssop is recommended as an expectorant, powdered stavesacre seeds are given for dropsy, and pennyroyal and thyme are prescribed for easing headache pain (Gruenwald 2007).

The author devotes a considerable amount of space to cephalalgia. $\mathrm{He}$ gives 744 recipes in the iatrosophion; of these, 106 or $14.2 \%$ deal with headaches, migraines, and general pains. Almost forty plant substances are used for headaches:

almonds, bitter

asphodel, leaves and root of

bramble, leaves of

cherry tree, sap of

frankincense

hyssop

labdanum

lentil

mastic gum

myrtle berry

nosesmart

oregano

peach, pit of

peppercorn

pondweed

rue, fruit and plant and seeds of

sloe tree, sap of

thyme

wormwood

Animal substances include:

bird's egg, white of

earthworms

pigeon, dried feces of

snail almonds, oil of

beans, broad

caper, fresh root of

chrysanthemum

ginger

ivy, leaves and buds of

laurel, leaves and berries of

marjoram

monk's pepper, seeds of

myrtle tree, shoots of

oleander, dried leaves of

peach tree, sap of

pennyroyal

pine tree, root of

reed, bark of

saffron

stavesacre

walnut

Minerals are iron rust, lead monoxide, quicklime, and salt, while other substances used are:

\author{
anointing oil \\ bread crumbs \\ honey \\ pine resin \\ rose water \\ vinegar, weak \\ wax \\ yeast
}

bird's egg, yolk of hedgehog, skin of sheep tallow wild pigeon, feces of ashes

coals, burning

oakum

pitch

vinegar, regular

water not drunk by mules or horses

wine 
All these ingredients - plants, animals, and minerals — are combined in various recipes as a means to treat headaches; for example,

If one has a headache because of a cold, take laurel berries and seeds of rue. Remove the covers. Take a root of the pine tree and vinegar. Boil these. Add a little wax and then apply to the head. Crack open a peach pit and grind it along with frankincense and vinegar. Soften and then place on the forehead with a cloth.[Take] finely ground seed of nosesmart and the burnt feces of a pigeon. Soften with vinegar and place upon the forehead. If one has a headache because of the sun beating down on him, take snails and crack them open. Mix the meat with ground frankincense and vinegar. Place this mixture on his forehead with a cloth. [Make sure that you] pestle the meat well first and then mix it with the other ingredients. (Papadogiannakēs 2001: 55)

For migraines, herbal and non-herbal compounds are smeared onto the side of the head affected with pain. For example, this series of recipes:

Take "the guts of the earth," that is, worms. Simmer them in a fire along with 15 crushed peppercorns. Mix these with vinegar and apply to the head. Grind the dung of wild pigeon dung and mix with vinegar; smear on. Boil seeds of monk's pepper in anointing oil. Beat and then apply to the forehead and temples. Soften quicklime with honey and apply. Take the fruit of the rue and place in the ears and on the head; press it firmly [onto the skin] and then cover [with cloth]. Pestle bitter almonds and kneaded mastic gum; mix with vinegar and smear on the forehead. Pestle the tender buds of ivy. Mix the juice with rose oil and vinegar and apply. Put dry oleander leaves into burning coals and have the patient breathe the fumes through his nose. Ground a fresh root of the caper plant and smear on. Pestle rue and mix with vinegar. Place on the area where the head aches. Boil oakum in vinegar; extract the pitch and sprinkle it with salt. Cover the head with this. Turn a hedgehog's skin into ash; mix with oil and apply. Take the leaves and root of an asphodel and turn into ash. Mix with oil and apply. (Papadogiannakēs 2001: 57-59)

While not a few ingredients, like vinegar, rue, almonds, and asphodel, may seem strange, they are excellent folk pharmacological remedies.

Any individual recipe may be effective (after all it would not have been recorded if it did achieve results), but it may not always work: patients vary, and species of plants may be different in various locales or not available. If so, then the Greek of the early modern period did what his classical and Byzantine ancestors had done: resort to religion and/or magic. Supernatural and supranatural methods were not rejected in medicine of the Tourkokratia as they are in today's modern medicine; any remedy was tried if it could promise hope for a cure. Thus, in his chapters on headache, Anagnōstēs offers religious prayers for headaches and migraines. For example,

Just as Solomon the wonderful annihilated the evil spirits of deceit, so too I give over you by the name of our Lord Jesus Christ; I give over you, O skull, cranium, mesocranium, the rheum, spasm, cold chills, inflammation, erysipelas, feverish shakes, and demons lurking on the outside. Our Lord Jesus Christ enjoins you, O 
Vol. 6, No. $1 \quad$ Oberhelman: Pharmacological and Non-Pharmacological Treatment...

evil spirits, to retreat into the wild mountains where no sound of birds is heard, where neither sun nor moon enters. You are also to depart from NN, the slave of God. On [the place of] the skull the Lord was crucified, on the wood of the cypress and pine and cedar trees, so that He might abrogate every activity of the devil. Let us stand well, let us stand with the fear of God. Amen. (Papadogiannakēs 2001: 59-60)

Sometimes magical letters or magical words (most of which are gibberish on the surface but supposedly contained the power to exorcise demons or illnesses) are joined with biblical verses and invocations of members of the Trinity:

Write on a sheet of paper the following [characters] and give it to the patient: Mikhaēl. Ekklēsourariz. Barsaphaēl. Eklèson. Rhix. [Write also the verse] "In the beginning was the Word." Akranou. Aphra. Aphikodamros. Phisazaēl. $\varphi v \kappa \delta \alpha v$ $\kappa \tau \tau \tau \varphi \lambda \tau \sigma v \rho \chi \tau *^{20}{ }^{2}$ (Papadogiannakēs 2001: 60)

Or, this combination of magical characters and gospel readings:

Write these and have [the sufferer] wear them [on the head]: Abra. Aphikodak. Aphizaēl. Phiktha. $\imath \pi$ i $\tau \varphi \pi \rho \%$. Also read into his ear 11 gospel readings from the Matins cycle. ${ }^{21}$

Some cures are magical in nature and consist of binding/unbinding spells or cures using the principle of similia similibus, where what one does to an object will have the same effect on the patient. The following is a cure for internal and external hemorrhoids:

Take a newly made knife-one that has never been used to cut anything beforeand on the fifth day of the moon's waning draw binding circles with it around three roots of ribwort plantain. [While doing this,] say: "In the name of the Father, the Son, and the Holy Spirit." Then cut out the roots with the knife and recite this prayer: "O God of heaven and earth and everything in them, holy trinity rulers of life, have mercy on us. Holy Lady Theotokos, Saint Lucian, Paul, the healing saints Cosmas and Damian, intercede with Holy God so that He may cause the internal and external hemorrhoids, as well as any other ailment, to shrivel up and vanish for $N N$, the son of $N N$ [masculine] and NN [feminine]. And just as this knife has made shavings on this plant, so may God shave away the internal and external hemorrhoids and perforations of the intestines and all diseases afflicting $N N$, the slave of God; for the intercession of the Blessed Theotokos and all the saints we glorify and give thanks to the Father, Son, and Holy Spirit, now and always, forever and ever. Amen." Immediately hang the plant roots over smoke and cause them to wither; if God wills it, the patient will be healed. (Papadogiannakēs 2001: 128)

\footnotetext{
${ }^{20}$ There are six-pointed stars painted in the text after this star.

${ }^{21}$ An example of magical words existing alongside religious words.
} 
Here, just as the roots are shaved by the knife, so God is asked to shave away the swollen hemorrhoids; and just as the plantain roots wither over a fire and its smoke, so too God will cause the hemorrhoids to wither. Notice, though, that even within this magical context, religion pervades and is critical for the effectiveness of the treatment. This is a clear example of how faith in Christianity can exist alongside with magic (cutting herbs on moonlit nights while chanting exorcisms) and with good pharmacology, as plantain is used in herbal medicine to treat intestinal problems.

One cure in Anagnōstēs' text for a headache incorporates all three methods of healing: religious (cruciform knots), folk medicine (binding cloth or similar materials pulled tightly across the skull to constrict the vessels and ease the pain), and magic (the cracking open of an egg for the yolk symbolizes that the cracking open of the skull so that the migraine will escaped from the patient):

One should place a batch of cotton on the sufferer's head and then tie this with cruciform knots from the forehead to the nape of the neck, and from one side of the head to the other. Take four bobbins. Twist a knot around each bobbin and tighten well. Pull the knots tight. Next crack a newly laid egg and place the yoke on the crown of his head. The pain will pass in but a short time. (Papadogiannakēs 2001, 54)

I would point out, incidentally, that modern studies have shown that cystine, the amino acid found in eggs, breaks down toxin acetaldehyde in the liver. This toxin is brought on by hangovers, and so eggs can help with headaches brought on by a hangover.

In the Theodorakis iatrosophion, headaches are not treated as extensively; rather, skin diseases are his main concern. It is not uncommon, however, for individual iatrosophia to emphasize particular diseases. Although each iatrosophion claims to treat all physical disorders, the fact is that each writer chose to highlight specific areas of the body, whether from his own interests or because certain ailments were more common in the locale where he lived.

Theodorakis records headache cures that range from good folk medicine to binding spells and sympathetic magic. In one section he offers three recipes:

For headache: Take vinegar and boil it, and add oakum and fine salt; put them on the head as a poultice/plaster. Similarly: Also raki, really hot, you should put it on the head. It is the perfect cure. (Another): The shell of the tortoise, you should burn it and make a powder, and you should mix it with pork fat, and pound Arum lily, and you should mix all together and anoint this person and he gets well. (Clark 2011: 113)

All these ingredients are found in ancient and Byzantine folk medicine. Vinegar has been a popular cure for head pain from Hippocrates down to the present day, while turtle shells and especially Arum lily are still used for such pain. On the island of Crete, raki is commonly considered a great way to treat headaches, as well as other ailments like colds, flu, diarrhea, and fever.

Another recipe combines raki with vegetables and fruits: 
For headache: Take one white onion, pound it, and Wallachian salt, and two paras worth of cinchona bark and 51 black raisins and very fine quality raki and beat them up well and put this on top; open out a blistering plaster on top of the neck. (Clark 2011: 101)

Both onions and black raisins are found in herbal books as a treatment for headaches, but the cinchona bark is interesting. This bark contains alkaloid compounds including quinine, and would be effective for headache pain.

Another recipe calls for an unusual application: placing a freshly chicken on the patient's head:

For headache: Take oil and hot butter to anoint his head, and you should take a live chicken, and you split it to its belly just as it is, with the intestines; you should put them behind onto the very top of his head on top of the pain, similarly you should put another one underneath on the chin of the neck. (Clark 2011: 125)

The magical method here is transference. By placing a chicken on the patient's head, the disease (or the pain) will be transferred from the head to the chicken.

A final section on headaches in this iatrosophion contains magical characters and exorcism prayers for expelling the headache or migraine:

For headache: Write the letters below at the waning of the moon: $\Xi . E . \Psi . \Theta . E$.

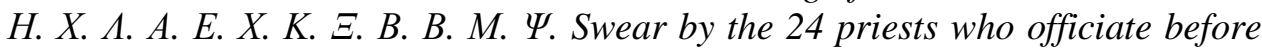
the throne of God, depart from the servant of the Lord, You endured the nails, Christ, and bowed [your] immaculate head and you saved your faithful people and your faithful robber. Dismiss the head(ache) and the migraine head from the servant of the Lord. Holy Angels of the Lord who keep the four rivers of paradise: Psouson, Geon, Tigris and Euphrates, keep also the head of the servant of the Lord. Write these at the waning of the moon and have him keep them on top of his head. (Clark 2011: 111)

This spell combines astrology (the waning of the moon), religious texts (the story of the penitent thief on the cross and passages from the book of Revelation), exorcism of the headache, and the use of a phylactery that the patient must wear on his skull. What we have is a marvelous syncretism of various belief systems working side by side to achieve healing.

In conclusion, the various recipes (medical, pharmacological, religious, and magical) in our two iatrosophia demonstrate how all methods of healing in post-Byzantine Crete were considered legitimate. Throughout the early modern era of Greece, medical practitioners came in many forms: herbalists, folk healers, priests, wise village men and women, magicians, old women in the family, as well as trained doctors. ${ }^{22}$ All these people were viewed in society as legitimate medical healers, for the medical practitioner was not necessarily one who possessed specialized, formal training, but anyone whose primary concern

\footnotetext{
${ }^{22}$ See more fully Jütte (2013); Oberhelman (2013: 1-31); and the special issue of Anthropology \& Medicine 23.2 (2016); for Europe generally, Gentilcore (1998) and Walker (2005); for Greece, Hionidou (2016).
} 
was the treatment of a sick person. People who were suffering from illness and were in pain did not care who cured them or even how they were cured. They were willing to consult anyone and to undergo any method of treatment, as long as health was restored.

\section{References}

Alexopoulou MP (1998) Das Iatrosophion des sog. Meletios: Edition mit sprachlichem und sachlichem Kommentar (The Iatrosophion of the so-called Meletios: Edition with linguistic and factual commentary). Ph.D. dissertation, Ludwig-Maximiliani-Universität München.

Barb AA (1966) The Mermaid and the Devil's Grandmother: A Lecture. Journal of the Warburg and Courtauld Institutes 29: 1-23.

Bennett D (2000) Medical Practice and Manuscripts in Byzantium. The Society for the Social History of Medicine 13: 279-291.

Betz HD (1992) The Greek Magical Papyri in Translation, Including the Demotic Spells. 2nd ed. Chicago: The University of Chicago Press.

Bradshear W (1979) Ein Berliner Zauberpapyrus (A Berlin magic papyrus). Zeitschrift für Papyrologie und Epigraphik 33: 261-278.

Carr AW (2003) Icons and the Object of Pilgrimage in Middle Byzantine Constantinople. Dumbarton Oaks Papers 56: 75-92.

Clark PA (2002) Landscape, Memories, and Medicine: Traditional Healing in Amari, Crete. Journal of Modern Greek Studies 20: 339-365.

Clark PA (2011) A Cretan Healer's Handbook in the Byzantine Tradition: Text, Translation and Commentary. London: Ashgate.

Csepregi I (2007) The Compositional History of Greek Christian Incubation Miracle Collections: Saint Thecla, Saint Cosmas and Damian, Saint Cyrus and John, Saint Artemios. Ph.D. dissertation, Central European University.

Csepregi I, Burnett C (Eds.) (2012) Ritual Healing: Magic, Ritual and Medieval Therapy from Antiquity until the Early Modern Period. Florence: Sismel-Edizioni Del Galluzzo.

Demetriades-Hadj AK (2015) Iatrosophikón: Folklore Remedies from a Cyprus Monastery: Original Text and Parallel Translation of Codex Machairas A.18. Nicosia: Foundation Anastasios G. Leventis.

Dijk JJ van, Geller MJ (2003) Ur III Incantations from the Frau Professor HilprechtCollection, Jena. Wiesbaden: Harrassowitz Verlag.

Eadie MJ (2012) Headaches through the Centuries. New York and Oxford: Oxford University Press.

Edelstein EJ, Edelstein L (1945) Asclepius: A Collection and Interpretation of the Testimonies. 2 vols. Baltimore: Johns Hopkins University Press; Reprint edition (March 20, 1998).

Gentilcore D (1998) Healers and Healing in Early Modern Italy. Manchester and New York: Manchester University Press.

Graf F (2014) Dangerous Dreaming: The Christian Transformation of Dream Incubation. Archiv für Religionsgeschichte 15: 117-144.

Gruenwald J (2007) Physicians' Desk Reference for Herbal Medicines. 4th ed. Montvale, NJ: Thomson.

Hamilton M (1906) Incubation: The Cure of Disease in Pagan Temples and Christian Churches. London: Simpkin, Marshall, Hamilton, Kent \& co. 
Vol. 6, No. $1 \quad$ Oberhelman: Pharmacological and Non-Pharmacological Treatment...

Hanlidou R, Karousou R, Kleftoyanni V, Kokkini S (2004) The Herbal Market of Thessaloniki (N. Greece) and Its Relation to the Ethnobotanical Tradition. Journal of Ethnopharmacology 91: 281-299.

Herzog P (1931) Die Wunderheilungen von Epidauros: Ein Beitrag zur Geschichte der Medizin und der Religion (The Miracle Healing of Epidaurus: A Contribution to the History of Medicine and Religion). Leipzig: Philologus Supplementband 22(3).

Hionidou V (2016) Popular Medicine and Empirics in Greece, 1900-1950: An Oral History Approach. Medical History 60(4): 492-513.

Jütte R (Eds.) (2013) Medical Pluralism. Past-Present-Future. Stuttgart: Franz Steiner Verlag.

Karenberg A, Leitz C (2001) Headache in Magical and Medical Papyri of Ancient Egypt. Cephalalgia 21: 911-916.

Koehler PJ, Boes CJ (2010) A History of Non-Drug Treatment in Headache, Particularly Migraine. Brain 133: 2489-2500.

Kotansky R (1980) Two Amulets in the Getty Museum. J P Getty Museum Journal 8: 181-187.

Kotansky R (1991) Incantations and Prayers for Salvation on Inscribed Greek Amulets. In CA Faraone and D Obbink (Eds.), Magika Hiera: Ancient Greek Magic and Religion, pp. 107-137. Oxford: Oxford University Press.

Kotansky R (2002). An Early Christian Gold Lamella for Headache. In P Mirecki and M Meyer (Eds.), Magic and Ritual in the Ancient World, pp. 37-46. Leiden: BRILL.

Lardos A (2006) The Botanical Materia Medica of the Iatrosophion-A Collection of Prescriptions from a Monastery in Cyprus. Journal of Ethnopharmacology 104: $387-406$.

Lardos A (2012) Historical Iatrosophia Texts and Modern Plant Usage in Monasteries on Cyprus. Ph.D. dissertation. University of London.

Lardos A, Heinrich M (2013) Continuity and Change in Medicinal Plant Use: The Example of Monasteries on Cyprus and Historical Iatrosophia Texts. Journal of Ethnopharmacology 150: 202-214.

LiDonnici LR (1992) Compositional Background of the Epidaurian IAMATA. American Journal of Philology 113: 25-41.

LiDonnici LR (1995) The Epidaurian Miracle Inscriptions: Text, Translation and Commentary. Atlanta: Scholars Press.

Magiorkinis E, Diamantis A, Mitsikostas D, Androustos G (2009) Headaches in Antiquity and during the Early Scientific Era. Journal of Neurology 256: 12151220.

Monette M (2012) The Medicine of the Prophet. Canadian Medical Association Journal 184: E649-650.

Norn S, Permin H, Kruse P, Kruse E (2009) From Willow Bark to Acetylsalicylic Acid. Dansk Medicinhistorisk Årbog 37: 79-98.

Oberhelman SM (Eds.) (2013) Dreams, Healing, and Medicine in Greece: From Antiquity to the Present. London: Ashgate.

Oberhelman SM (2014) Anatomical Votive Reliefs as Evidence for Specialization at Healing Sanctuaries in the Ancient Mediterranean World. Athens Journal of Health 1(1): 47-62.

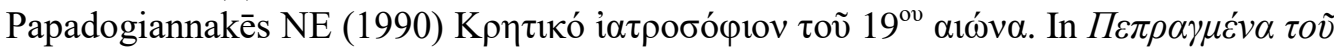

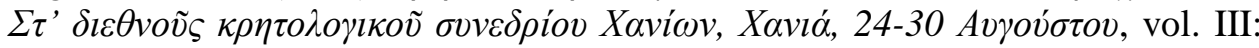
345-366. Xavió.

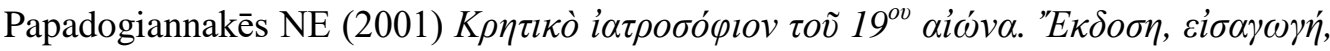
$\sigma \eta \mu \varepsilon l \omega ́ \sigma \varepsilon l \varsigma . ~ P \varepsilon ́ \theta v \mu v o v$. 
Papadopoulos C (2009) Post-Byzantine Medical Manuscripts: New Insights into the Greek Medical Tradition, Its Intellectual and Practical Interconnections, and Our Understanding of Greek Culture. Journal of Modern Greek Studies 27: 107-130.

Pfohl G (1977) Inschriften der Griechen. Epigraphische Quellen zur Geschichte der Antiken Medizin (Inscriptions of the Greeks. Epigraphic sources on the history of ancient medicine). Darmstadt: WBG Darmstadt.

Ploeg G van D (2018) The Impact of the Roman Empire on the Cult of Asclepius. Oxford: Oxford University Press.

Rapoport A, Edmeads J (2000) The Evolution of Our Knowledge. Archives of Neurology 57: 1221-1223.

Renberg GH (2017) Where Dreams May Come: Incubation Sanctuaries in the GrecoRoman World. 2 vols. Leiden: BRILL.

Riddle J (1985) Dioscorides on Pharmacy and Medicine. Austin: University of Texas Press.

Roebuck C (1951) The Asklepieion and Lerna. Corinth 14: iii-xi+xiii+1$173+175+177-182$.

Rose FC (1995) The History of Migraine from Mesopotamian to Medieval Times. Cephalalgia Supplement 15: 1-3.

Steger F (2017) Asklepios: Medizin und Kult (Asklepios: medicine and cult). Stuttgart: Franz Steiner Verlag.

Talbot A-M (2002) Pilgrimage to Healing Shrines: The Evidence of Miracle Accounts. Dumbarton Oaks Papers 56: 153-173.

Talbot A-M (2010) The Miracles of Gregory Palamas by Philotheos Kokkinos. In P Stephenson (Eds.), The Byzantine World, pp. 236-247. London and New York: Routledge.

Touwaide A (2007) Byzantine Hospitals Manuals (Iatrosophia) as a Source for the Study of Therapeutics. In B Bowers (Eds.), The Medieval Hospital and Medical Practice, 147-173. London: Routledge.

Trompoukis C, Vadikolias K (2007) The "Byzantine Classification" of Headache Disorders. Headache 47: 1063-1068.

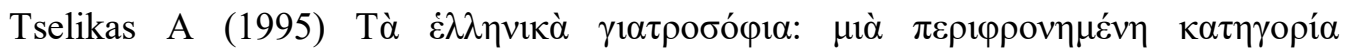

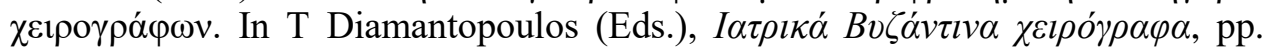
57-69. A $\theta \eta \dot{v} \alpha: \triangle \mathrm{OMO} \Sigma$.

Valentino D (2017) Das Iatrosophion des Codex Taur. B.VII.18, Muenchner Arbeiten zur Byzantinistik (The Iatrosophion of the Codex Taur. B.VII.18, Muenchner's work on Byzantine Studies), vol. 1. Ars Una Verlag UG.

Walker TD (2005) Doctors, Folk Medicine and the Inquisition: The Repression of Magical Healing in Portugal during the Enlightenment. Boston: BRILL.

Wellmann M (Eds.) (1906-1914) Pedanii Dioscoridis Anazarbei de materia medica libri quinque. 3 volumes. Berlin: Weidmann. (Reprints: 1958 and 2000)

Wickkiser B (2009) Asclepius, Medicine, and the Politics of Healing in Fifth-Century Greece. Baltimore: John Hopkins University Press.

Zarshenas M, Petramfar P, Firoozabadi A, Moein MR, Mohagheghzadeh A (2013) Types of Headache and Those Remedies in Traditional Persian Medicine. Pharmacognosy Reviews 7(13): 17-26.

Zayas V (2007) On Headache Tablets: Headache Incantations from Ur III (2113-2038 BC). Medicine and Health 90: 46-48. 
